CASE REPORT

\title{
Acute coronary syndrome
}

\author{
Saad Jawaid, Adeel Chaudary
}

Emergency Department, Leicester Royal Infirmary, University Hospital of Leicester, Leicester, UK

\section{Correspondence to}

Dr Saad Jawaid dr.saad@ymail.com

Accepted 23 May 2014

\section{SUMMARY}

The paramedics brought a 60-year-old man to the emergency department after a sudden onset of shortness of breath with a subsequent drop in the Glasgow Coma Scale (GCS). On arrival the patient looked peri-arrest. His $\mathrm{O}_{2}$ saturations were $84 \%$ on $15 \mathrm{~L}$ of oxygen. He had gasping breathing with a completely silent chest and the GCS was $6 / 15(E=1, V=1, M=4)$. The blood gas revealed type-2 respiratory failure. The chest $X$-ray was unremarkable and ECG was not indicative for cardiac catheterisation lab activation. Bedside shock scan was done which showed global hypokinesia of the left ventricle. In spite of unconvincing ECG and chest X-ray, an acute cardiac event was diagnosed in view of an abnormal bedside echo. The patient was transferred to the cardiac catheterisation lab for urgent percutaneous coronary intervention which revealed critical stenosis of the left main stem coronary artery, which was successfully stented. The patient had a good recovery from the life-threatening event.

\section{BACKGROUND}

Patients with undifferentiated shock can be a real challenge for the Emergency Physician. To diagnose the underlying cause in a shocked patient in a timely manner is vital as the treatment options may be completely different and are also time critical. It is imperative for emergency physicians to equip themselves with ultrasound skills as it can play a key role in the patient's management.

This case is an excellent example of the importance of bedside ultrasound scan utilisation. The patient's presentation was very atypical for an acute coronary event. His bedside ECG (figure 1) and chest X-ray (CXR; figure 2) were not helpful in the diagnosis until an ultrasound scan (video 1) revealed a significant left ventricle wall motion abnormality and explained the patient's condition.

\section{CASE PRESENTATION}

Our patient was a 60-year-old man who was brought to the emergency department (ED) by paramedics after a sudden onset of shortness of breath.

On scene when attended by the paramedics the patient was in significant respiratory distress and was diaphoretic. There was no history of chest pain. On arrival to the ED, he was unresponsive but the airway was patent. The patient's breathing effort was very poor and he was gasping. His trachea was central and chest was completely silent. His breathing was supported initially with a bag valve mask and then subsequently the patient was intubated in view of his low Glasgow Coma Scale (GCS). He was easy to ventilate and the chest movements were bilateral and equal. His first blood pressure reading was $170 / 110 \mathrm{~mm} \mathrm{Hg}$ and pulse rate was about $120 / \mathrm{min}$. His neck veins were not engorged and he had equal blood pressure in both arms. His GCS was $6 / 15(\mathrm{E}=1, \mathrm{~V}=1, \mathrm{M}=4)$. The rest of the examination was unremarkable. We could not figure out the cause of the patient's acute deterioration after completing the primary survey.

The patient was continuously monitored and serial ECGs were carried out. The ECGs were discussed with the Cardiology Registrar who was not convinced of any acute cardiac event.

The patient had no significant medical or surgical history and was not on any medications.

\section{INVESTIGATIONS}

Routine bloods in the ED were:

- Haemoglobin $158 \mathrm{~g} / \mathrm{L}$

- White cell count $17.1 \times 10^{9} / \mathrm{L}$

- Sodium $136 \mathrm{mmol} / \mathrm{L}$

- Potassium $4 \mathrm{mmol} / \mathrm{L}$

- Urea $6.1 \mathrm{mmol} / \mathrm{L}$

- Creatinine $97 \mu \mathrm{mol} / \mathrm{L}$

- Estimated glomerular filtration rate $73 \mathrm{~mL} / \mathrm{min} /$ $\mathrm{L} .73 \mathrm{~m}^{2}$

- C reactive protein $<5 \mathrm{mg} / \mathrm{L}$

- Troponin I $115 \mu \mathrm{g} / \mathrm{L}$

- International normalised ratio 1.0

- D-dimer $0.95 \mu \mathrm{g} / \mathrm{L}$

- Arterial blood gas: pH 6.98, $\mathrm{pCO}_{2} 16.02 \mathrm{kPa}$, $\mathrm{pO}_{2} 21.7 \mathrm{kPa}, \mathrm{HCO}_{3} 27.8 \mathrm{mmol} / \mathrm{L}$, base excess -7.5 , lactate 2.7 .

CXR showed no significant pathology.

ECG showed sinus tachycardia with left ventricular hypertrophy.

Focused bedside cardiac ultrasound $\operatorname{scan}^{1}$ and shock $\operatorname{scan}^{2}$ conducted by the ED Registrar showed global hypokinesia of the left ventricle.

Official echo performed later by the cardiologist showed severe systolic dysfunction and apical thrombus.

The coronary angiogram revealed severe ostial stenosis of the left main coronary artery.

\section{DIFFERENTIAL DIAGNOSIS}

A patient with low GCS, shortness of breath and type- 2 respiratory failure may have wide differentials like life-threatening asthma, tension pneumothorax, acute cardiac events or massive pulmonary embolism. Treatment of each is quite different and time critical. An early shock scan using ultrasound helped us narrow our differential towards a cardiac pathology. 


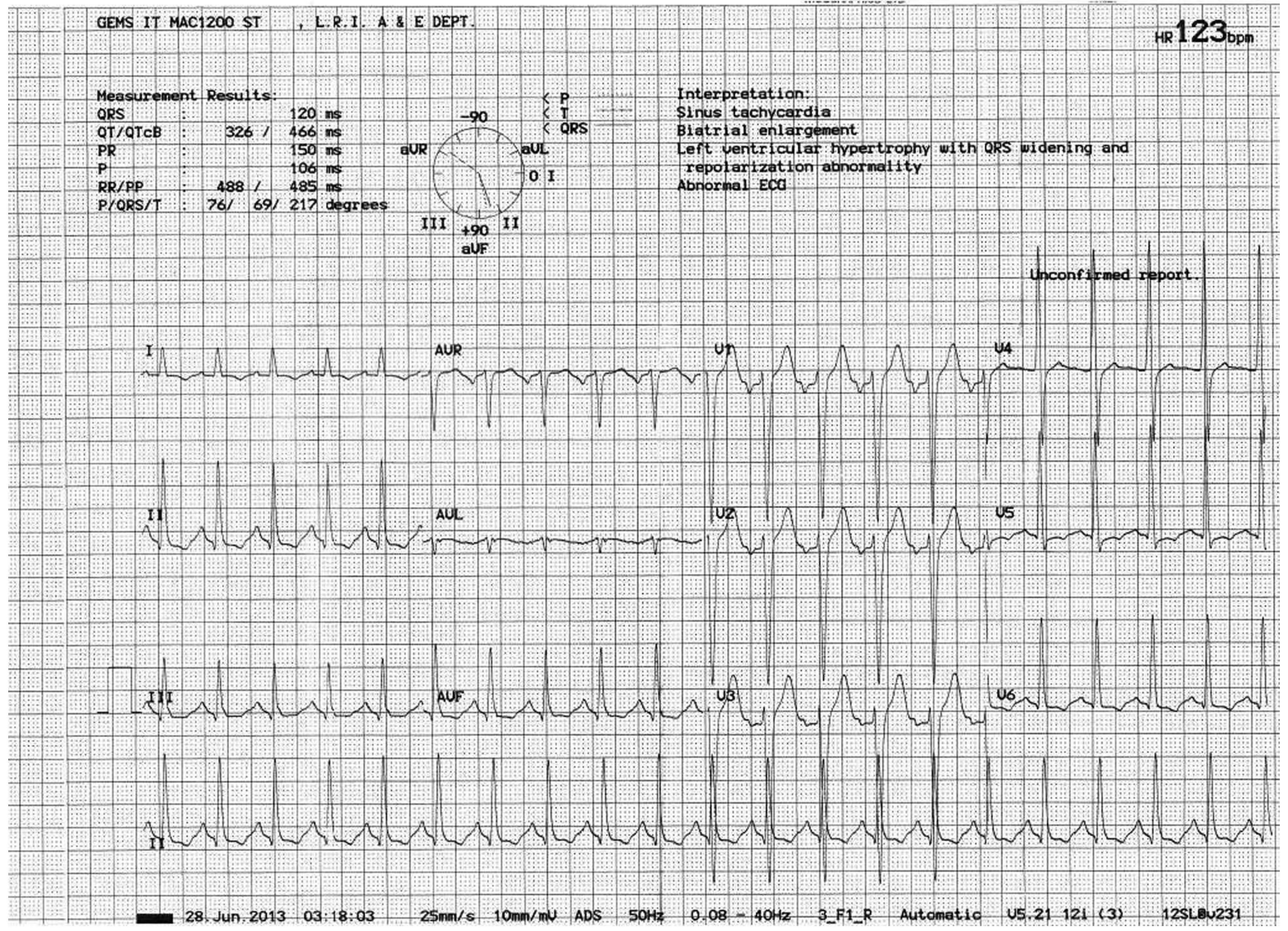

Figure 1 ECG showing sinus tachycardia with QRS at upper normal limit of 120 ms. The voltage criteria for left ventricular hypertrophy is met. No features to suggest acute ST-elevation myocardial infarction are obvious.

\section{TREATMENT}

On the way to hospital, paramedics had given the patient salbutamol and ipratropium nebulisation, intravenous hydrocortisone $(100 \mathrm{mg})$ and intravenous furosemide $(40 \mathrm{mg})$.

In the ED, initially the patient's breathing was supported with bag-valve-mask ventilation with $15 \mathrm{~L}$ of $\mathrm{O}_{2}$. The patient was also given intravenous salbutamol $0.5 \mathrm{mg}$ bolus, magnesium sulfate $2 \mathrm{~g}$ and $500 \mathrm{~mL}$ of $0.9 \%$ normal saline.

ITU were consulted to secure the airway. The patient was intubated and transferred to the cardiac catheterisation laboratory for immediate percutaneous coronary intervention (PCI).

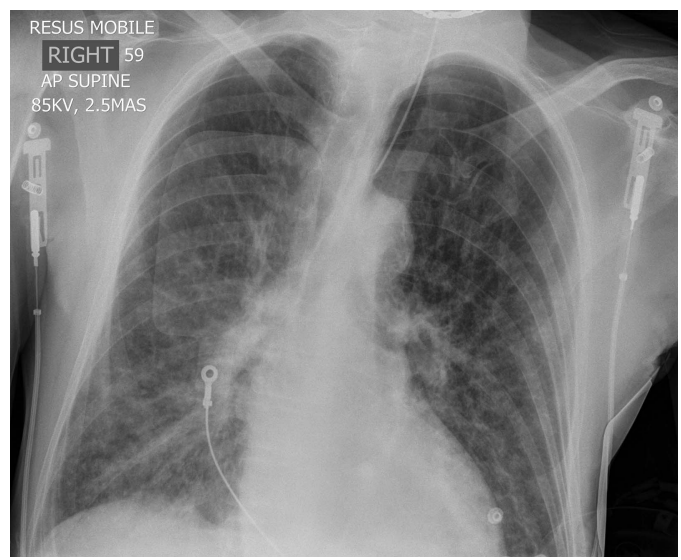

Figure 2 Chest anteroposterial supine X-ray not showing any major areas of airspace opacification or pneumothorax.

\section{OUTCOME AND FOLLOW-UP}

A $4.5 \times 13 \mathrm{~mm}$ stent was placed in the left main artery during emergency PCI. Postprocedure, the patient was admitted to the intensive care unit for 1 day and then transferred to the ward for monitoring. After a few days of observation the patient was discharged home with medicines and for follow-up in the cardiology clinic.

\section{DISCUSSION}

We found the patient's presentation very challenging. The patient had no chest pain and had low GCS. His CXR and ECG

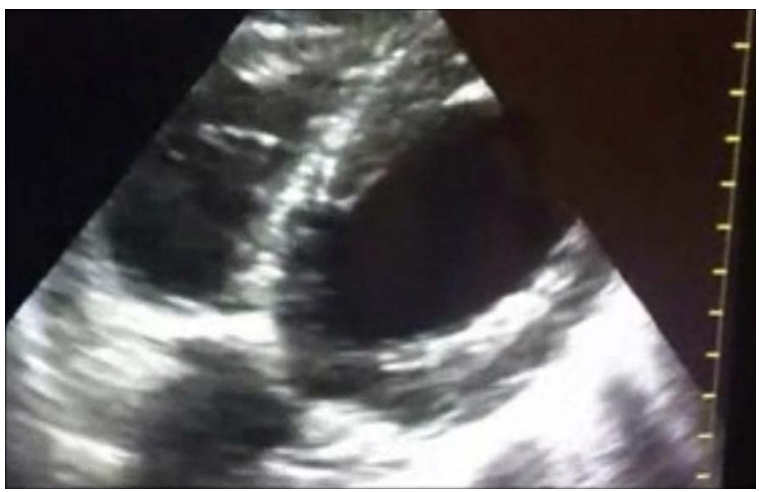

Video 1 A sub-xiphoid view of heart during bedside ultrasound shock scan shows almost globally akinetic left ventricle. Right ventricle seems to be contracting normally. No pericardial fluid was seen. 
were non-diagnostic. Atypical presentations in acute coronary syndrome are known phenomenon where there is absence of chest pain. Although some high-risk factors have been identified, ${ }^{3}$ for example older age (72.9 years), female gender, nonwhite race and comorbidities (diabetes, stroke and heart failure); our patient had none of them. The National Registry of Myocardial Infarction 2 database showed that 33\% patients did not present with chest pain. ${ }^{4}$ Patients with myocardial infarction without chest pain are less quickly diagnosed and treated and have higher adjusted odds of hospital mortality, regardless of whether they have an ST-segment elevation. ${ }^{5}$ The presence of silent chest is a possible presentation in early stages of cardiogenic shock and has mortality of about $70 \%$ due to the difficulty in diagnosis. ${ }^{7}$ Although our patient was presented atypically with very little history available as a result of low GCS and non-specific ECG, a quick bedside (see video 1) echo which showed a globally hypokinetic left ventricle proved to be a life saver as the right diagnosis was made and critical minutes were saved by not making other unnecessary investigations such as CT of the head.

\section{Learning points}

- Ultrasound is an important tool for emergency and acute care physicians.

- Bedside ultrasound should be performed early during the initial assessment of sick medical patients to diagnose life-threatening emergencies.

- Acute coronary syndrome (ACS) with flash pulmonary oedema can mimic life-threatening asthma and respiratory failure.

- Atypical presentations of ACS should always be kept in mind.
Bedside ultrasound is widely used by most physicians during the management of trauma patients but its use in the assessment of sick medical patients is still not considered an important diagnostic tool. There is enough evidence ${ }^{8}$ to suggest that the use of ultrasound during the initial assessment of sick medical patients can increase the diagnostic accuracy significantly as shown in this case.

Contributors Both the authors have dealt with the patient and contributed to the case report.

Competing interests None.

Patient consent Obtained.

Provenance and peer review Not commissioned; externally peer reviewed.

\section{REFERENCES}

1 Labovitz AJ, Noble VE, Bierig M, et al. Focused cardiac ultrasound in the emergent setting: a consensus statement of the American Society of Echocardiography and American College of Emergency Physicians. J Am Soc Echocardiogr 2010;23:1225-30.

2 Perera P, Mailhot T, Riley D, et al. The RUSH exam: rapid ultrasound in shock in the evaluation of the critically ill. Emerg Med Clin North Am 2010;28:29-56.

3 Canto JG, Rogers WJ, Goldberg RJ, et al. Association of age and sex with myocardial infarction symptom presentation and in-hospital mortality. JAMA 2012; 307:813-22

4 Canto JG, Shlipak MG, Rogers WJ, et al. Prevalence, clinical characteristics, and mortality among patients with myocardial infarction presenting without chest pain. JAMA 2000;283:3223-9.

5 Canto AJ, Kiefe $\mathrm{Cl}$, Goldberg RJ, et al. Differences in symptom presentation and hospital mortality according to type of acute myocardial infarction. Am Heart $J$ 2012;163:572-9.

6 Brieger D, Eagle KA, Goodman SG, et al. Acute coronary syndromes without chest pain, an underdiagnosed and undertreated high-risk group: insights from the Global Registry of Acute Coronary Events. Chest 2004;126:461-9.

7 Judith SH, Christopher EB, Lynn AS, et al. Cardiogenic shock complicating acute myocardial infarction - etiologies, management and outcome: a report from the SHOCK trial registry. J Am Coll Cardiol 2000;36(3s1):1063-70.

8 Jones AE, Tayal VS, Sullivan DM, et al. Randomized, controlled trial of immediate versus delayed goal-directed ultrasound to identify the cause of non-traumatic hypotension in emergency department patients. Crit Care Med 2004;32:1703-8.

Copyright 2014 BMJ Publishing Group. All rights reserved. For permission to reuse any of this content visit

http://group.bmj.com/group/rights-licensing/permissions.

BMJ Case Report Fellows may re-use this article for personal use and teaching without any further permission.

Become a Fellow of BMJ Case Reports today and you can:

- Submit as many cases as you like

- Enjoy fast sympathetic peer review and rapid publication of accepted articles

- Access all the published articles

- Re-use any of the published material for personal use and teaching without further permission

For information on Institutional Fellowships contact consortiasales@bmjgroup.com

Visit casereports.bmj.com for more articles like this and to become a Fellow 